\title{
Beta endorphin modulation of the glucoregulatory effects of repeated epinephrine infusion in alloxan-diabetic and normal dogs
}

\author{
K. M.A.El-Tayeb, M. Vranic, P. L. Brubaker and H. L.A. Lickley \\ Departments of Physiology, Surgery and Medicine and Women's College Hospital, University of Toronto, Toronto, Canada
}

\begin{abstract}
Summary. When repeated epinephrine infusions are given to normal dogs as a partial stress model, there is exaggerated hyperglycaemia, associated with reduced plasma insulin levels and markedly decreased glucose clearance. In the present study, we have examined the hormonal and metabolic responses to two successive 60 -min epinephrine $\left(0.1 \mu \mathrm{g} \cdot \mathrm{kg}^{-1}\right.$. $\min ^{-1}$ ) infusions with or without concomitant infusion of beta endorphin $\left(0.3 \mu \mathrm{g} \cdot \mathrm{kg}^{-1} \cdot \mathrm{min}^{-1}\right)$ in 6 alloxan-diabetic dogs. These studies have been compared to similar studies in 5 normal dogs.
\end{abstract}

In the diabetic dogs, plasma glucose rose from $12.3 \pm 2.2$ to $16.2 \pm 2.4 \mathrm{mmol} / 1(p<0.001)$ in response to the first epinephrine infusion and rose further to $18.1 \pm 2.5 \mathrm{mmol} / 1(p<$ 0.001 ) during the second epinephrine infusion. The increases in plasma glucagon and glucose production were comparable with both infusions, but considerably greater than previously observed in normal dogs.

In normal dogs, beta endorphin diminished the insulin response to the first epinephrine infusion $(p<0.02)$, and abolished this response to the second $(p<0.05)$. In addition beta endorphin also diminished the glucagon response to the second epinephrine infusion $(p<0.01)$ and greatly potentiated epinephrine-induced suppression of glucose metabolic clearance during both infusions $(p<0.001)$. However, beta endorphin did not appreciably alter the hyperglycaemic response to epinephrine due to a concomitant attenuation of the epinephrine-induced increase in hepatic glucose production.

In contrast to normal dogs, beta endorphin did not modulate the effects of either the first or second epinephrine infusion on glucose kinetics in diabetic dogs. Also, beta endorphin failed to inhibit glucagon or insulin secretion in response to epinephrine in the diabetic animals. Since the alloxan-diabetic and normal dogs respond differently to the combined infusion of beta endorphin and epinephrine we conclude that the effects of beta endorphin observed in the normal dogs are dependent upon intact pancreatic endocrine function.

Key words: Glucose turnover, hepatic glucose production, glucose disappearance, glucose clearance, glucagon, insulin, cortisol, free fatty acids.
Epinephrine plays an important role in regulation of the hormonal and metabolic responses to stress. Severe stress is associated with impaired carbohydrate metabolism, in normal individuals $[1,2]$, and can lead to deterioration of metabolic control in diabetic patients [3]. Many stress situations involve repeated insults; for example, infection supervening upon trauma. In a previous study [4] we used repeated epinephrine infusions $\left(0.1 \mu \mathrm{g} \cdot \mathrm{kg}^{-1} \cdot \mathrm{min}^{-1}\right)$ to simulate a component of moderate-to-severe repeated stress, in normal dogs. Although there were equivalent increases in plasma glucagon and hepatic glucose production during the two successive epinephrine infusions, there was a diminished insulin response and a greater decrease in the metabolic clearance of glucose in response to the second epinephrine infusion, resulting in somewhat exag- gerated hyperglycaemia. In the present study we have given repeated epinephrine infusions to alloxan-diabetic dogs, as the effects of repetitive stress on glucoregulation have not been examined in diabetes. These animals are characterised by a $50 \%$ reduction in basal insulin levels and their pancreatic B cells are virtually unresponsive to epinephrine [5].

It has been reported recently that opioid peptide levels are elevated in Type 1 (insulin-dependent) diabetic patients [6]. As both the endogenous opiates and epinephrine are released in stress $[7,8]$, we also wished to investigate the interactions between beta endorphin and epinephrine in glucoregulation, in diabetes. In normal dogs [4], we have previously reported that beta endorphin $\left(0.06 \mu \mathrm{g} \cdot \mathrm{kg}^{-1} \cdot \mathrm{min}^{-1}\right)$ diminished the insulin and glucagon responses to repeated epinephrine in- 
fusions. There was an enhanced hyperglycaemic response attributable mainly to a greater suppression of glucose clearance. In the present study, a repeated epinephrine infusion $\left(0.1 \mu \mathrm{g} \cdot \mathrm{kg}^{-1} \cdot \mathrm{min}^{-1}\right)$ was given alone or together with beta endorphin $\left(0.3 \mu \mathrm{g} \cdot \mathrm{kg}^{-1}\right.$. $\min ^{-1}$ ) to alloxan-diabetic dogs and normal dogs. This allowed us to assess whether the effects of interactions between beta endorphin and epinephrine on glucose kinetics and pancreatic glucagon secretion require the intact function of the pancreatic B cell. We chose to infuse beta endorphin at $0.3 \mu \mathrm{g} \cdot \mathrm{kg}^{-1} \cdot \mathrm{min}^{-1}$, as the existence of multiple opiate receptors with different sensitivities to the endogenous opiates have been described $[9,10]$, and it has been reported that the effects of the opiates and opioid peptides on glucose metabolism are dose-dependent [11-13].

\section{Materials and methods}

Experiments were conducted on 6 mongrel dogs weighing $19-23 \mathrm{~kg}$ rendered diabetic by intravenous injection $(65 \mathrm{mg} / \mathrm{kg})$ of alloxan (BDH Chemicals, Poole, UK), injected intravenously 3 weeks before the experimental studies. Regular insulin (10-15 U) and Neutral Protamine Hagedorn (NPH) insulin (10-15 U, pork insulin, Connaught Laboratories, Willowdale, Ontario, Canada) were injected daily in the diabetic dogs after glycosuria became evident. Pork insulin was used because it does not induce formation of antibodies for at least 2 months and thus plasma insulin levels could be accurately determined [14]. Insulin dosage was adjusted daily to keep glycosuria below $1 \%$. Studies were also carried out on 5 comparable normal dogs. All animals were maintained on a daily diet of $200 \mathrm{~g}$ Purina dog chow and $200 \mathrm{~g}$ beef chunks (Romar Pet Supplies, Toronto, Ontario, Canada). At least 3 days before each experiment, venous catheters were placed under general anaesthesia. For infusion purposes 3 catheters were placed into the jugular vein with the tips in the superior vena cava, and for sampling, a cannula was introduced into the saphenous vein and advanced until the tip was just below the hepatic vein.

\section{Experimental design}

Food was removed $16 \mathrm{~h}$ prior to each study, which commenced between 08.00-09.00 hours. In the diabetic dogs, NPH insulin was omitted the day before each experiment and 3 doses of regular insulin were given. The first dose $(10-15 \mathrm{U})$ at 10.00 hours, the second $(5-10 \mathrm{U})$ at 16.00 hours and the third $(2-5 \mathrm{U})$ at 22.00 hours. This treatment regimen allowed an adequate control of glycaemia while avoiding the presence of exogenous insulin during the experiments.

Two protocols were used. The first ( $n=6$ diabetic dogs) consisted of: (a) a 40-min control period, (b) a 60 -min infusion of epinephrine $\left(0.1 \mu \mathrm{g} \cdot \mathrm{kg}^{-1} \cdot \mathrm{min}^{-1}\right)$, (c) a 60 -min recovery period, (d) a second 60 -min infusion of epinephrine $\left(0.1 \mu \mathrm{g} \cdot \mathrm{kg}^{-1} \cdot \mathrm{min}^{-1}\right)$ and (e) a second $60-\mathrm{min}$ recovery period. This infusion rate of epinephrine gives rise to levels comparable to moderate-to-severe stress [15]. The second protocol ( $n=6$ diabetic dogs and $n=5$ normal dogs) was similar, with the addition of beta endorphin $\left(0.3 \mu \mathrm{g} \cdot \mathrm{kg}^{-1} \cdot \mathrm{min}^{-1}\right)$, commencing $30 \mathrm{~min}$ prior to the start of the epinephrine infusion, and continuing throughout the duration of the experiment. At least 1 week was allowed between studies in each animal. For comparative purposes, we have included the results from studies in which repeated epinephrine infusions without the addition of beta endorphin were given to normal dogs. Although these results have been reported previously [4], they were carried out concurrently with the present studies.

\section{Materials}

Epinephrine hydrochloride (Parke Davis and Co. Ltd., Brockville, Ontario, Canada) was stabilised with $1 \mathrm{mg} / \mathrm{ml} \mathrm{L}$-ascorbic acid (BDH chemicals, Toronto, Ontario, Canada), in normal saline. Synthetic human B-endorphin (Peninsula Laboratories, San Carlos, Calif, USA) was dissolved immediately before use in normal saline containing $0.5 \mathrm{ml}$ dog plasma as a protein carrier.

\section{Tracer methods}

Glucose tritiated at the third carbon position $(5 \mu \mathrm{Ci} / \mathrm{ml}$, New England Nuclear Canada, Ltd, Lachine, Canada) was infused at a rate of $0.1 \mathrm{ml} / \mathrm{min}$ to measure glucose turnover. A priming dose, equivalent to the amount infused for $140 \mathrm{~min}$ (diabetic dogs) or $100 \mathrm{~min}$ (normal dogs) was given at the start of the experiment. A period of $140 \mathrm{~min}$ (diabetic dogs) or $100 \mathrm{~min}$ (normal dogs) was allowed for tracer equilibration.

The rates of hepatic glucose production or glucose appearance and glucose disappearance were calculated using the non-steady state equations developed by Steele [18] and validated by Radziuk et al. [19]. Total glucose clearance rate was calculated by dividing $\mathrm{Rd}$ by the prevailing glucose concentration. This represents an estimate of glucose utilisation partially corrected for the mass effect of the prevailing glycaemia and although it is recognised that it is not totally independent of plasma glucose concentrations it does give some measure of insulin action. The validity and meaning of the measurement of metabolic glucose clearance has been recently examined [20]. In the normal dogs, glucose clearance represents glucose metabolic clearance. In diabetic dogs, however, total glucose clearance includes both metabolic and renal clearance when plasma glucose levels are higher than the threshold of renal excretion $(11 \mathrm{mmol} / \mathrm{l})$.

\section{Laboratory methods}

Plasma concentrations of glucose, insulin (IRI), glucagon (IRG), catecholamines, cortisol, beta endorphin and free fatty acids (FFA) were determined as described previously $[4,16,17]$.

\section{Statistical analysis}

Statistical significance was evaluated by the unpaired Student's t-test to compare responses to treatments in two different groups of animals, or paired t-test to compare responses to different treatments in the same dogs [21]. A factorial analysis of variance using Statistical Analysis Systems (SAS Institute, Carey, NC, USA) was used to assess overall responses.

\section{Results}

\section{Hormonal and metabolic effects of a repeated epinephrine infusion in alloxan-diabetic dogs}

Alloxan-diabetic dogs were characterised by basal hyperglucagonaemia $(150 \pm 29$ vs $52 \pm 5 \mathrm{pmol} / 1, p<$ $0.005)$ and slight hypoinsulinaemia $(7.6 \pm 1.4$ vs $11.7 \pm$ $1.5 \mathrm{mU} / 1$, NS). We saw similar fasting IRI values in alloxan-diabetic dogs $(6 \pm 0.4 \mathrm{mU} / 1)$ in previous studies [5] and these were significantly lower than in normal dogs. In the present study, the IRI values were considerably more variable and the difference between the normal and diabetic dogs did not reach statistical significance. Plasma glucose concentrations were elevated $(11.8 \pm 1.5$ vs $5.6 \pm 0.2 \mathrm{mmol} / 1, p<0.001)$, rates of glu- 


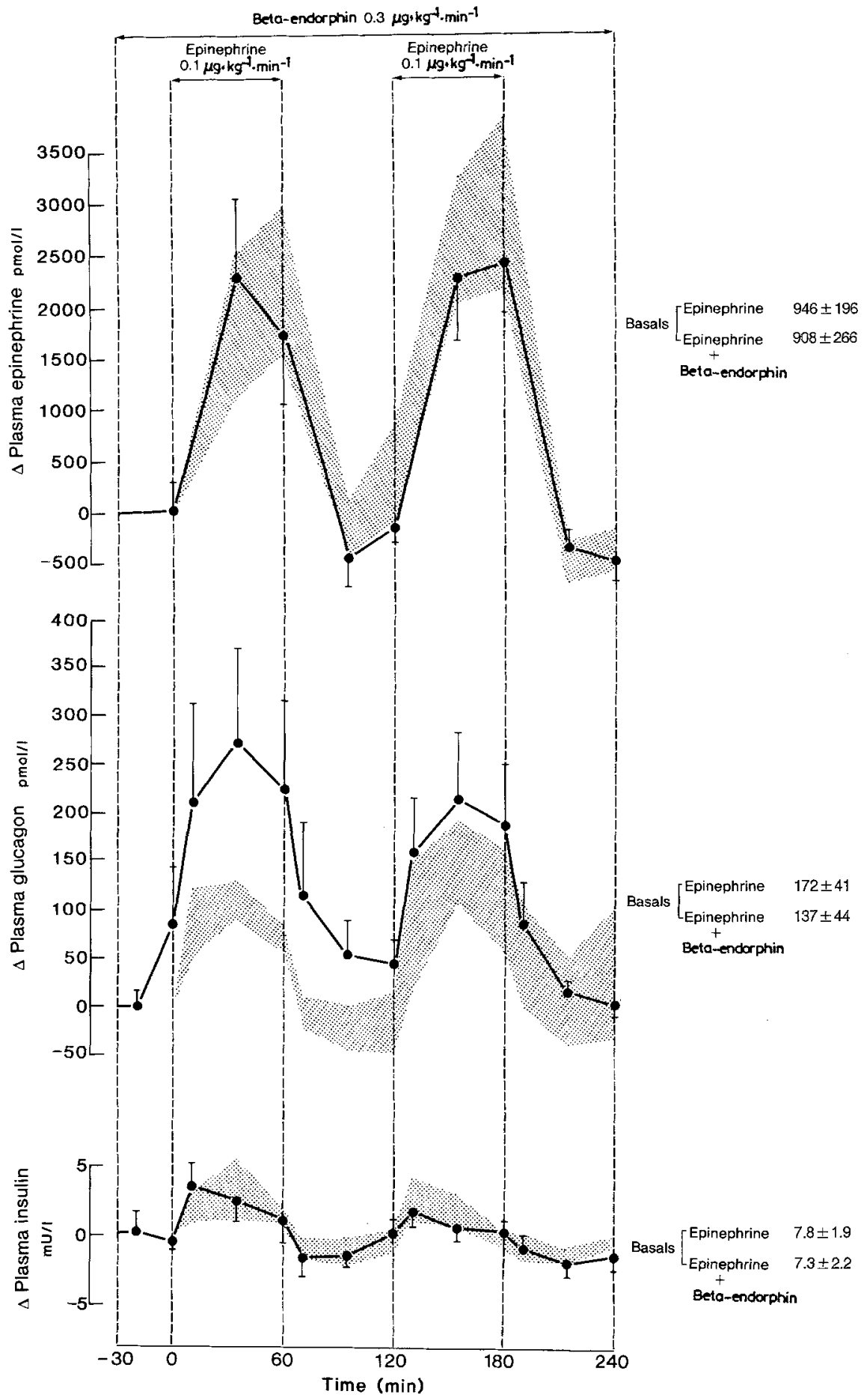

Fig.1. Effects of repeated infusion of epinephrine $\left(0.1 \mu \mathrm{g} \cdot \mathrm{kg}^{-1} \cdot \mathrm{min}^{-1}\right)$ alone $(\mathrm{B})$ or together with beta endorphin $(0.3 \mu \mathrm{g}$. $\mathrm{kg}^{-1} \cdot \mathrm{min}^{-1}, \longrightarrow$ ), in 6 alloxan-diabetic dogs. Concentrations of plasma epinephrine, glucagon and insulin are shown as deviations $(\triangle)$ from the average control values indicated. Values are expressed as mean \pm SEM cose production $\left(\mathrm{R}_{\mathrm{a}}, 25.0 \pm 2.2\right.$ vs $20.6 \pm 1.7 \mu \mathrm{mol}$. $\left.\mathrm{kg}^{-1} \cdot \mathrm{min}^{-1}, \mathrm{NS}\right)$ and disappearance $\left(\mathrm{R}_{\mathrm{d}}, 27.2 \pm 3.2 \mathrm{vs}\right.$ $\left.20.6 \pm 1.7 \mu \mathrm{mol} \cdot \mathrm{kg}^{-1} \cdot \mathrm{min}^{-1}, p<0.05\right)$ were also slightly increased while the glucose clearance was substantially decreased $\left(2.4 \pm 0.1\right.$ vs $3.7 \pm 0.2 \mathrm{ml} \cdot \mathrm{kg}^{-1} \cdot \mathrm{min}^{-1}$, $p<0.001$ ).

With repeated epinephrine infusion (Fig. 1, shaded area) plasma epinephrine levels increased from a basal of $946 \pm 196$ to $3212 \pm 625 \mathrm{pmol} / 1(p<0.05)$ during the first epinephrine infusion, and to $3946 \pm 750 \mathrm{pmol} / 1$ $(p<0.05)$ during the second, in the diabetic dogs. The increments in plasma epinephrine during the two infusion periods were not statistically different. Plasma glucagon increased from a basal of $172 \pm 41$ to $228 \pm$ $37 \mathrm{pmol} / \mathrm{l}(p<0.01)$, and declined to basal levels during the first recovery period. In response to the second epinephrine infusion, however, plasma glucagon increased to $309 \pm 61 \mathrm{pmol} / 1 \quad(p<0.02)$ and remained suprabasal during the subsequent recovery period $(\mathrm{F}=6.60, p<0.01$ compared to the first recovery period). Plasma insulin levels did not rise significantly during either epinephrine infusion. 


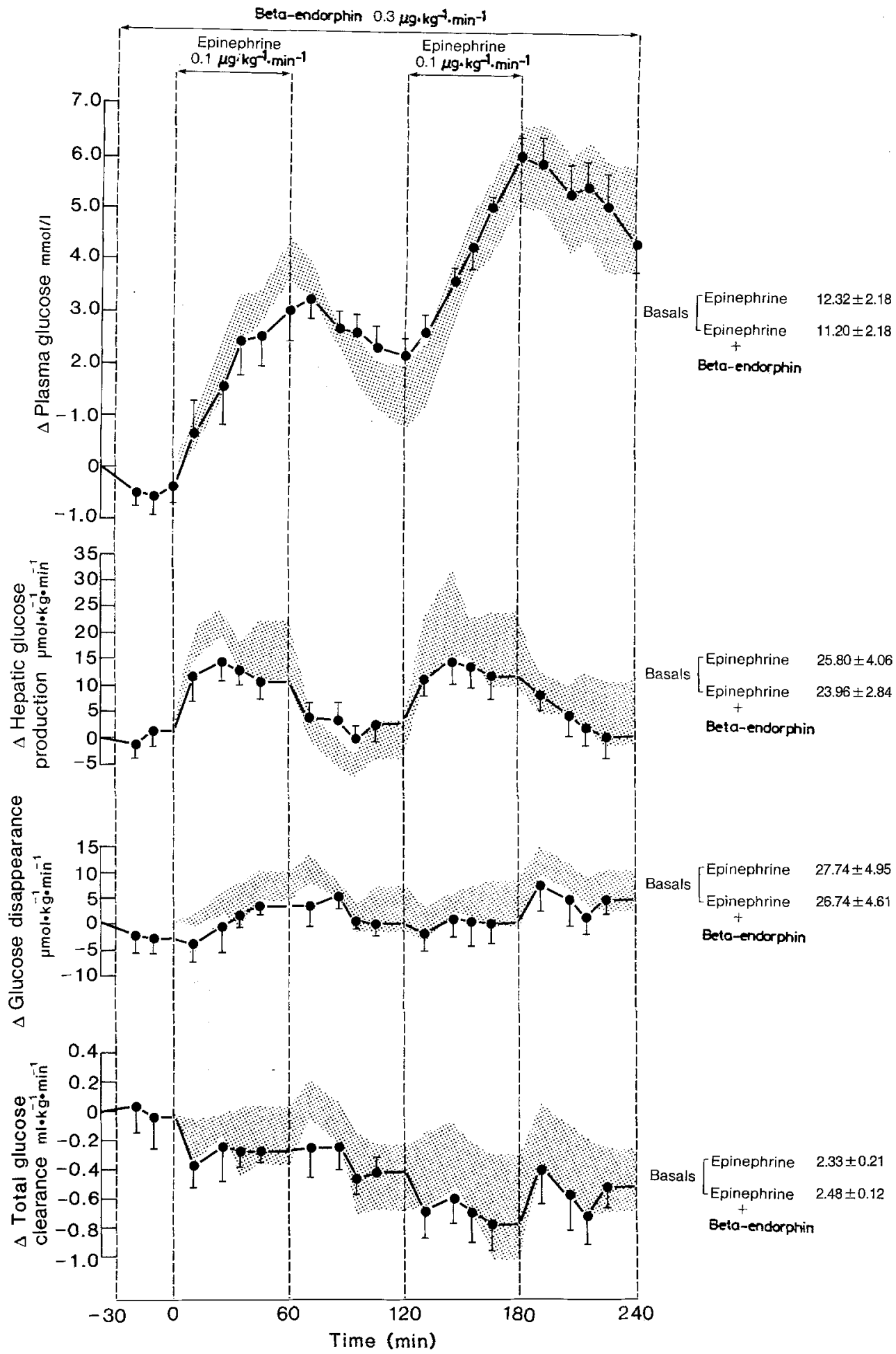

Fig. 2. Effects of repeated infusion of epinephrine $\left(0.1 \mu \mathrm{g} \cdot \mathrm{kg}^{-1} \cdot \mathrm{min}^{-1}\right)$ alone (圈), or together with beta endorphin $\left(0.3 \mu \mathrm{g} \cdot \mathrm{kg}^{-1} \cdot \mathrm{min}^{-1}\right.$, - in 6 alloxan-diabetic dogs. Plasma concentrations and rates of production, utilisation, and total clearance of glucose, are shown as deviations $(\Delta)$ from the average control values indicated. Glucose production, utilisation and clearance are plotted at midpoints of the time intervals for which they were calculated. Values are expressed as mean \pm SEM

As shown in Figure 2, plasma glucose increased from a basal of $12.3 \pm 2.2$ to $16.2 \pm 2.4 \mathrm{mmol} / 1(p<$ 0.001 ) during the first epinephrine infusion, but declined to only $13.6 \pm 1.8 \mathrm{mmol} / 1$ by the end of the first recovery period. In response to the second epinephrine infusion, plasma glucose increased to $18.1 \pm$ $2.5 \mathrm{mmol} / 1(p<0.001)$ and was still elevated at $17.1 \pm$ $2.6 \mathrm{mmol} / 1(p<0.01)$ by the end of the subsequent recovery period. Thus, plasma glucose levels were higher
$(\mathrm{F}=23.97, p<0.001)$ in response to the second epinephrine infusion. There was a sustained increase in hepatic glucose production to $47.6 \pm 5.2 \mu \mathrm{mol} \cdot \mathrm{kg}^{-1}$. $\min ^{-1}(p<0.001)$ and $49.8 \pm 11.3 \mu \mathrm{mol} \cdot \mathrm{kg}^{-1} \cdot \mathrm{min}^{-1}$ $(p<0.05)$ during the two epinephrine infusions. Glucose disappearance increased to $34.8 \pm 7.1 \mathrm{umol}$. $\mathrm{kg}^{-1} \cdot \min ^{-1}(p<0.05)$ during the first infusion period but did not change significantly in response to the second epinephrine infusion. Glucose clearance de- 
K.M.A. El-Tayeb et al.: Beta endorphin-epinephrine interactions in diabetes

Table 1. Plasma cortisol and free fatty acid concentrations in response to repeated infusion of epinephrine $\left(0.1 \mu \mathrm{g} \cdot \mathrm{kg}^{-1} \cdot \mathrm{min}-1\right)$ in 6 alloxandiabetic dogs

\begin{tabular}{|c|c|c|c|c|c|c|c|c|c|c|c|c|c|}
\hline \multirow{2}{*}{ Time (min) } & \multirow{2}{*}{$\begin{array}{l}\text { Control } \\
0\end{array}$} & \multicolumn{3}{|c|}{ Epinephrine } & \multicolumn{3}{|c|}{ Recovery } & \multicolumn{3}{|c|}{ Epinephrine } & \multicolumn{3}{|c|}{ Recovery } \\
\hline & & 10 & 35 & 60 & 70 & 95 & 120 & 130 & 155 & 180 & 190 & 215 & 240 \\
\hline Cortisol $(\mathrm{mmol} / 1)$ & $\begin{array}{r}160 \\
47\end{array}$ & $\begin{array}{r}204 \\
47\end{array}$ & $\begin{array}{r}185 \\
30\end{array}$ & $\begin{array}{r}110 \\
19\end{array}$ & $\begin{array}{r}102 \\
19\end{array}$ & $\begin{array}{l}69 \\
11\end{array}$ & $\begin{array}{r}61 \\
8\end{array}$ & $\begin{array}{r}58 \\
8\end{array}$ & $\begin{array}{l}63 \\
13\end{array}$ & $\begin{array}{r}47 \\
8\end{array}$ & $\begin{array}{l}80 \\
30\end{array}$ & $\begin{array}{r}41 \\
6\end{array}$ & $\begin{array}{r}36 \\
6\end{array}$ \\
\hline $\mathrm{FFA}(\mu \mathrm{mol} / 1)$ & $\begin{array}{r}918 \\
\pm 146\end{array}$ & $\begin{array}{r}1413 \\
\pm 165\end{array}$ & $\begin{array}{r}1354 \\
\pm 188\end{array}$ & $\begin{array}{r}1326 \\
\pm 305\end{array}$ & & & $\begin{array}{r}650 \\
\pm 138\end{array}$ & $\begin{array}{r}1522 \\
\pm 200\end{array}$ & $\begin{array}{r}1452 \\
\pm 264\end{array}$ & $\begin{array}{r}1517 \\
\pm 322\end{array}$ & & & $\begin{array}{r}1144 \\
\pm 223\end{array}$ \\
\hline
\end{tabular}

Table 2. Plasma beta endorphin concentrations (nmol/1) during beta endorphin infusion $\left(0.3 \mu \mathrm{g} \cdot \mathrm{kg}^{-1} \cdot \mathrm{min}^{-1}\right.$ from -30 to $\left.240 \mathrm{~min}\right)$ in $5 \mathrm{nor}-$ mal and 6 alloxan-diabetic dogs

\begin{tabular}{|c|c|c|c|c|c|c|}
\hline & Basal & Control & $\begin{array}{l}\text { First } \\
\text { epinephrine } \\
\text { infusion }\end{array}$ & $\begin{array}{l}\text { First } \\
\text { recovery } \\
\text { period }\end{array}$ & $\begin{array}{l}\text { Second } \\
\text { epinephrine } \\
\text { infusion }\end{array}$ & $\begin{array}{l}\text { Second } \\
\text { recovery } \\
\text { period }\end{array}$ \\
\hline Normal dogs & $0.05 \pm 0.01$ & $4.7 \pm 1.2$ & $3.8 \pm 1.1$ & $3.7 \pm 1.1$ & $4.3 \pm 1.6$ & $2.6 \pm 0.7$ \\
\hline Diabetic dogs & $\mathrm{a}$ & $15.1 \pm 3.4$ & $12.3 \pm 3.3$ & $18.3 \pm 1.6$ & $19.0 \pm 3.3$ & $29.0 \pm 6.0$ \\
\hline
\end{tabular}

a Less than limits of sensitivity of the assay $(0.02 \mathrm{nmol} / \mathrm{l})$

Table 3. Plasma cortisol and free fatty acids (FFA) concentrations when beta endorphin $\left(0.3 \mu \mathrm{g} \cdot \mathrm{kg}^{-1} \cdot \mathrm{min}^{-1}\right)$ is given during repeated epinephrine $\left(0.1 \mu \mathrm{g} \cdot \mathrm{kg}^{-1} \cdot \mathrm{min}^{-1}\right)$ infusions, in 6 alloxan-diabetic dogs

\begin{tabular}{|c|c|c|c|c|c|c|c|c|c|c|c|c|c|c|c|}
\hline \multirow{3}{*}{ Time (min) } & \multicolumn{15}{|c|}{ Beta endorphin } \\
\hline & \multirow{2}{*}{$\frac{\text { Basal }}{-30}$} & \multicolumn{2}{|c|}{ Control } & \multicolumn{3}{|c|}{ Epinephrine } & \multicolumn{3}{|c|}{ Recovery } & \multicolumn{3}{|c|}{ Epinephrine } & \multicolumn{3}{|c|}{ Recovery } \\
\hline & & -20 & 0 & 10 & 35 & 60 & 70 & 95 & 120 & 130 & 155 & 180 & 190 & 215 & 240 \\
\hline Cortisol (mmol/1) & $\begin{array}{r}246 \\
\pm \quad 83\end{array}$ & $\begin{array}{r}243 \\
\pm \quad 88\end{array}$ & $\begin{array}{r}179 \\
\pm \quad 63\end{array}$ & $\begin{array}{r}160 \\
\pm \quad 50\end{array}$ & $\begin{array}{r}127 \\
\pm \quad 33\end{array}$ & $\begin{array}{r}99 \\
\pm \quad 33\end{array}$ & $\begin{array}{r}94 \\
+33\end{array}$ & $\begin{array}{r}61 \\
\pm 22\end{array}$ & $\begin{array}{r}52 \\
\pm \quad 8\end{array}$ & $\begin{array}{r}44 \\
\pm \quad 8\end{array}$ & $\begin{array}{r}69 \\
+\quad 28\end{array}$ & $\begin{array}{r}41 \\
\pm \quad 8\end{array}$ & $\begin{array}{r}75 \\
\pm \quad 19\end{array}$ & $\begin{array}{r}4 \\
+1\end{array}$ & $\begin{array}{l}4130 \\
11 \pm\end{array}$ \\
\hline FFA $(\mu \mathrm{mol} / \mathrm{l})$ & $\begin{array}{r}1100 \\
\pm 252\end{array}$ & $\begin{array}{r}922 \\
\pm 200\end{array}$ & $\begin{array}{r}905 \\
\pm 269\end{array}$ & $\begin{array}{r}1165 \\
\pm 225\end{array}$ & $\begin{array}{r}1382 \\
\pm 310\end{array}$ & $\begin{array}{r}1317 \\
\pm 355\end{array}$ & & & $\begin{array}{r}759 \\
+285\end{array}$ & $\begin{array}{r}1362 \\
\pm 362\end{array}$ & $\begin{array}{r}1417 \\
\pm 329\end{array}$ & $\begin{array}{r}1394 \\
\pm 331\end{array}$ & & & $\begin{array}{r}986 \\
\pm 285\end{array}$ \\
\hline
\end{tabular}

creased significantly following the first epinephrine infusion $(p<0.001)$ and also during the second epinephrine infusion $(\mathrm{F}=14.96, p<0.0002)$ and recovery $(\mathrm{F}=9.35, p<0.003)$ period.

The effects of repeated epinephrine infusion on plasma cortisol and free fatty acid (FFA) levels are shown in Table 1. Plasma cortisol decreased below basal levels during the first recovery period $(\mathrm{F}=22.93$, $p<0.0001)$, second epinephrine infusion $(\mathrm{F}=36.44$, $p<0.0001)$ and second recovery $(\mathrm{F}=38.31, p<0.0001)$ period. The increases in plasma FFA levels in response to the two epinephrine infusions were similar $(\mathrm{F}=17.86, p<0.0002$ during the first and $\mathrm{F}=30.02$, $p<0.0001$ during the second infusion).

\section{Hormonal and metabolic responses to repeated epinephrine infusion with beta endorphin in alloxan-diabetic dogs}

Plasma beta endorphin levels were below the limits of sensitivity of the assay $(0.02 \mathrm{nmol} / \mathrm{l})$ and rose throughout the study to a final value of $29 \pm 6 \mathrm{nmol} / 1(p<0.01$,
Table 2). The 30-min infusion of beta endorphin prior to epinephrine did not significantly alter any of the other hormonal or metabolic parameters examined (Figs. 1 and 2). The addition of beta endorphin to repeated epinephrine infusions resulted in similar increments in plasma epinephrine to those observed during infusion of epinephrine alone. Beta endorphin augmented glucagon secretion during the first epinephrine infusion $(\mathrm{F}=18.22, p<0.0004)$ and first recovery ( $\mathrm{F}=8.65, p<0.0081$ ) period (Fig. 1 ) but did not significantly alter the effects of epinephrine on insulin secretion (Fig.1), glucose concentrations or kinetics (Fig.2), cortisol or FFA levels (Table 3).

\section{Hormonal and metabolic responses to repeated epinephrine infusion with beta endorphin in normal dogs}

Plasma beta endorphin levels were $0.05 \pm 0.01$ and rose to a maximum value of $4.7 \pm 1.2 \mathrm{nmol} / 1$ after $30 \mathrm{~min}$ of infusion $(p<0.02)$ and remained suprabasal throughout the study (Table 2). The beta endorphin levels were significantly lower than seen in the alloxan-diabetic 


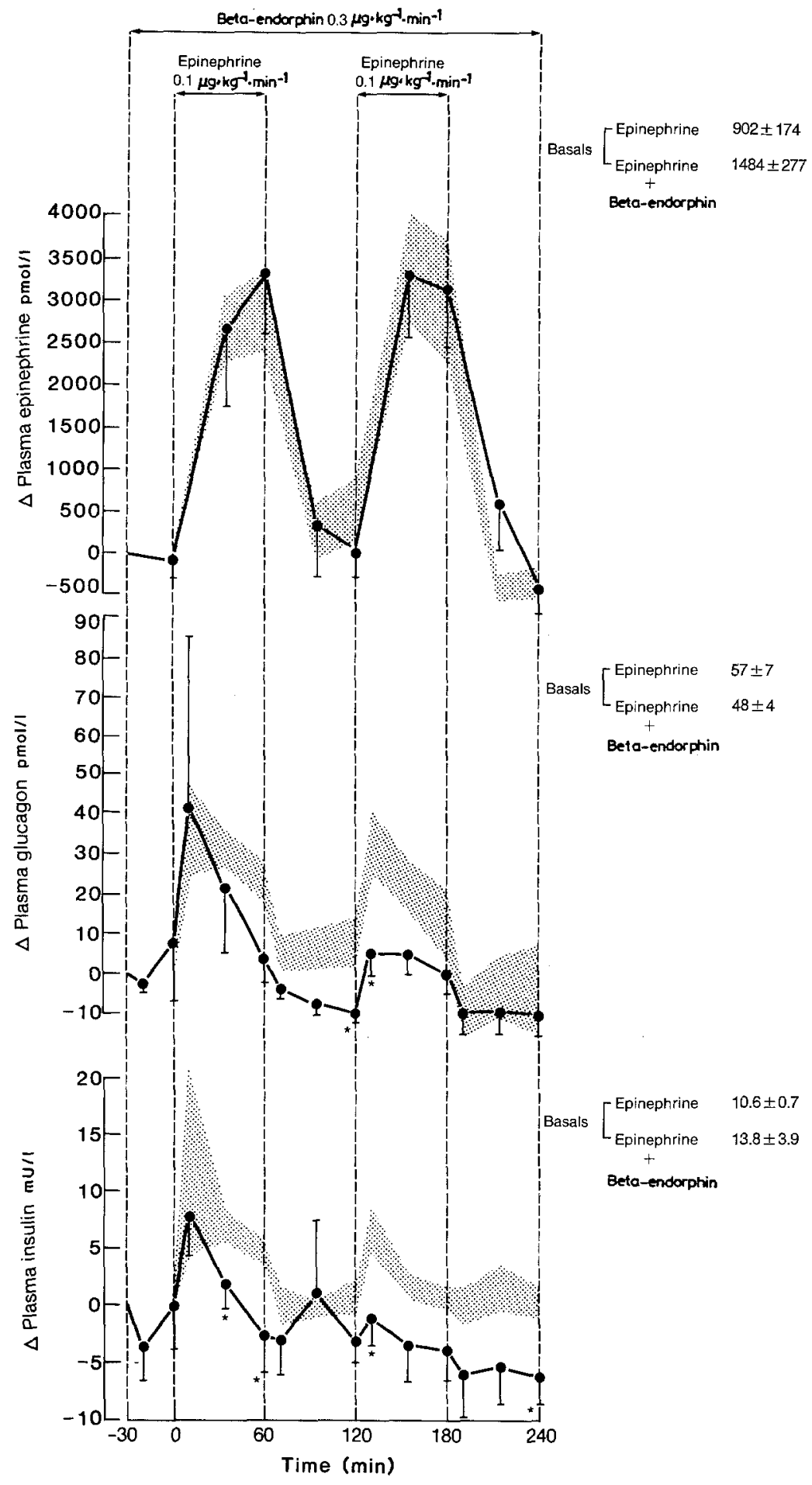

Fig. 3. Effects of infusion of epinephrine $\left(0.1 \mu \mathrm{g} \cdot \mathrm{kg}^{-1} \cdot \mathrm{min}^{-1}\right)$ together with beta endorphin $\left(0.3 \mu \mathrm{g} \cdot \mathrm{kg}^{-1} \cdot \mathrm{min}^{-1}, \longrightarrow\right)$, in 5 normal dogs. Concentrations of plasma epinephrine, glucagon, and insulin are shown as deviations $(\Delta)$ from the average control values indicated. Values are expressed as mean $\pm S E M$. For comparison, effects of infusion of epinephrine $\left(0.1 \mu \mathrm{g} \cdot \mathrm{kg}^{-1} \cdot \mathrm{min}^{-1}\right)$ alone (웅) are included (4). Differences between the responses in the two sets of studies are indicated (*) animals $(p<0.05)$. The 30 -min infusion of beta endorphin prior to the first epinephrine infusion (Figs. 3 and 4) did not significantly alter plasma epinephrine, glucagon, insulin or glucose concentrations. There were transient decreases in $\mathrm{R}_{\mathrm{a}}(p<0.01), \mathrm{R}_{\mathrm{d}}$ (NS) and glucose metabolic clearance $(p<0.05), 10 \mathrm{~min}$ after the start of the infusion. The data with respect to repeated epinephrine infusion in normal dogs (shaded area) has been reported elsewhere [4]. The rises in plasma epinephrine seen during the two epinephrine infusions were not affected by beta endorphin (Fig. 3). During the first infusion of epinephrine and beta endorphin, there were only transient increases in plasma glucagon and insulin (NS). The IRI levels were lower than observed during infusion of epinephrine alone $(p<0.02)$. During the recovery period, the levels of glucagon were subbasal and lower than with epinephrine alone $(p<0.05)$. The glucagon and insulin responses to the second infusion of epinephrine were abolished by administration of beta endorphin $(p<0.01$ and $p<0.05$ 


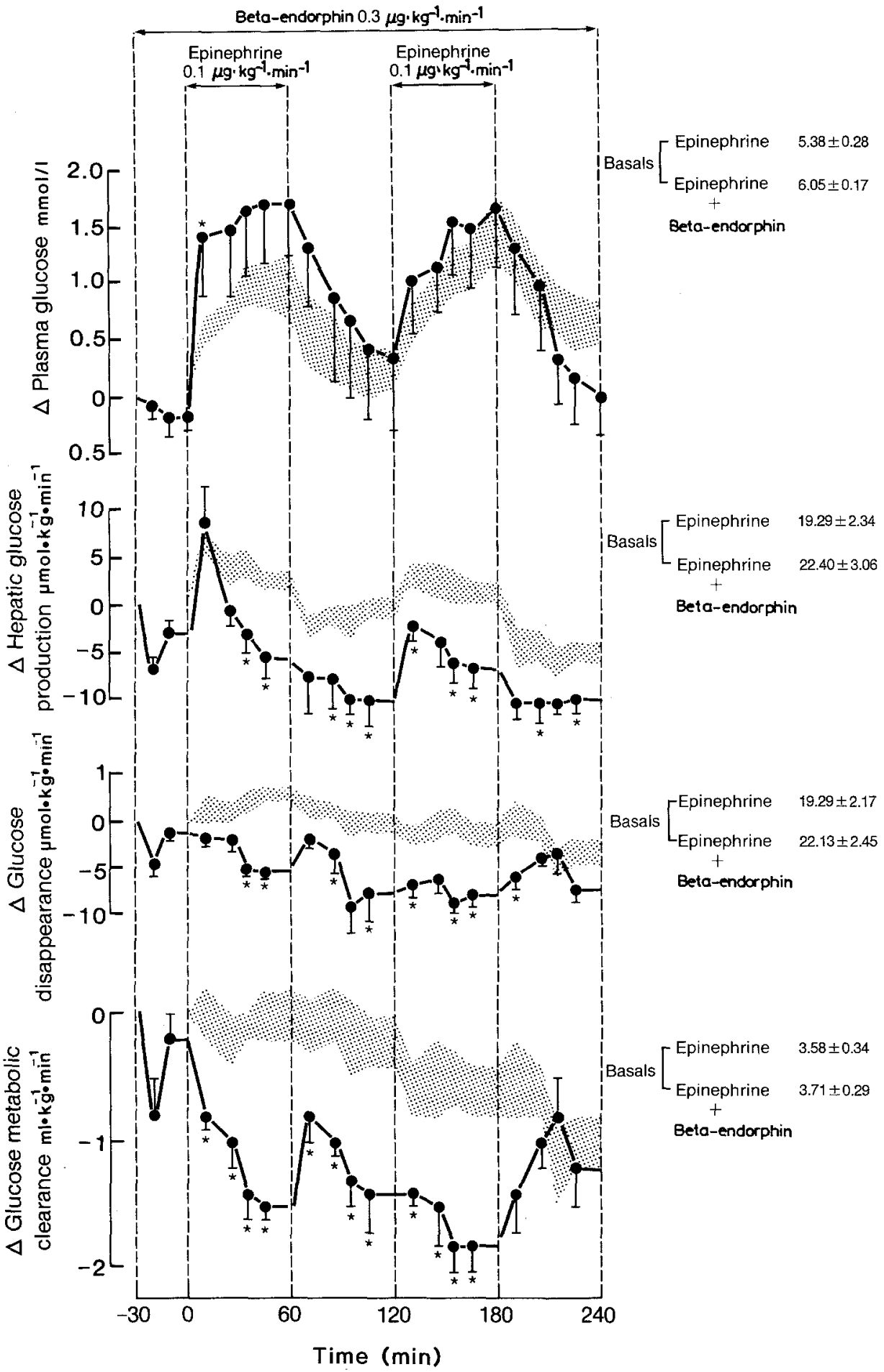

Fig. 4. Effects of repeated infusion of epinephrine $\left(0.1 \mu \mathrm{g} \cdot \mathrm{kg}^{-1} \cdot \mathrm{min}^{-1}\right)$ together with beta endorphin $\left(0.3 \mu \mathrm{g} \cdot \mathrm{kg}^{-1} \cdot \mathrm{min}^{-1}\right)$, in 5 normal dogs $(-$ ). Plasma concentrations and rates of production, utilisation and metabolic clearance of glucose, are shown as deviations $(\Delta)$ from the average control values indicated. Glucose production, utilisation and metabolic clearance are plotted at midpoints of the time intervals for which they were calculated. Values are expressed as mean $\pm S E M$. For comparison, effects of infusion of epinephrine $\left(0.1 \mu \mathrm{g} \cdot \mathrm{kg}^{-1} \cdot \mathrm{min}^{-1}\right)$ alone (⿴囗⿱一一⿱⿴囗十丌) included (4). Differences between the responses in the two sets of studies are indicated $(*)$

Table 4. Plasma cortisol and free fatty acids (FFA) concentrations when beta endorphin $\left(0.3 \mu \mathrm{g} \cdot \mathrm{kg}^{-1} \cdot \mathrm{min}^{-1}\right)$ is given during repeated epinephrine $\left(0.1 \mu \mathrm{g} \cdot \mathrm{kg}^{-1} \cdot \mathrm{min}^{-1}\right)$ infusions, in 5 normal dogs

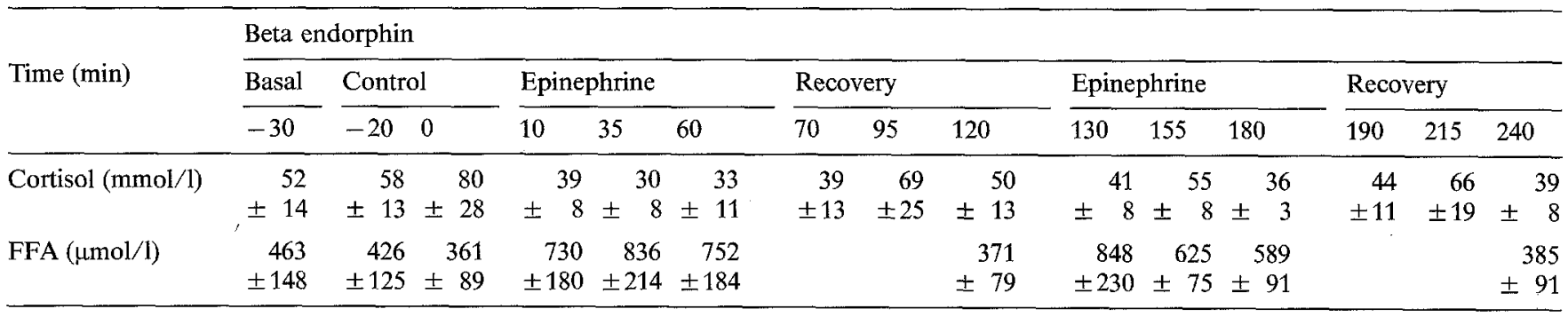


when compared to infusion of epinephrine alone), and remained subbasal during the second recovery period. As shown in Figure 4, beta endorphin markedly decreased $\mathbf{R}_{\mathrm{d}}(p<0.001)$ and glucose metabolic clearance $(p<0.01)$ during both epinephrine infusions. $\mathrm{R}_{\mathrm{a}}$ was also suppressed $(p<0.01)$, therefore, greater hyperglycaemia was only seen at the 10 -min time point of the first epinephrine and beta endorphin infusion $(p<$ 0.05 ). Thus, beta endorphin did not appreciably modify the glycaemic response to epinephrine infusions, as the decrease in glucose clearance was balanced by the concomitant decrease in Ra. Plasma cortisol and FFA levels were not altered by the infusions of epinephrine and beta endorphin (Table 4). The changes in plasma FFA were similar to those observed with epinephrine infusion alone in normal dogs [4].

\section{Discussion}

The present study was undertaken to examine hormonal and metabolic responses to repeated stress stimuli, in alloxan-diabetic dogs. We have also examined the role of the endocrine pancreas in determining beta endorphin-epinephrine interactions in glucoregulation by comparing studies in normal and diabetic dogs.

The hyperglycaemic response to epinephrine was greater in alloxan-diabetic dogs than in normal dogs, due largely to an exaggerated and sustained increase in hepatic glucose production $\left(\mathrm{R}_{\mathrm{a}}\right)$. This could reflect an exaggerated increase in plasma glucagon in response to both epinephrine infusions. In both diabetic and normal dogs, the changes in plasma glucagon levels and $\mathbf{R}_{\mathrm{a}}$ during the second epinephrine infusion were similar to those seen during the first infusion. In the normal dogs there was a greater increase in plasma glucose levels in response to the second epinephrine infusion, related to decreased glucose clearance [4]. In the diabetic animals, the higher plasma glucose levels seen during the second epinephrine infusion did not reflect a greater glycaemic response, but a failure of plasma glucose levels to return to basal after the first epinephrine infusion. This is possibly due to the decrease in glucose clearance seen during the first recovery period. Thus, although metabolic control progressively deteriorated in the diabetic dogs, the repeated stress stimuli per se did not appear to be the main determinant of this phenomenon.

The infusion of beta endorphin $\left(0.3 \mu \mathrm{g} \cdot \mathrm{kg}^{-1}\right.$. $\mathrm{min}^{-1}$ ) in normal dogs, slightly diminished the insulin and glucagon responses to the first epinephrine infusion, but virtually abolished these responses to the second. Other investigators have shown that beta endorphin stimulates the release of insulin and glucagon [22, 23]; however, it is possible that beta endorphin acts differently on pancreatic A and B cells already stimulated by epinephrine. The most impressive finding in the present study was that beta endorphin greatly potentiated the suppressive effect of epinephrine on glucose metabolic clearance in the setting of comparable glycaemia. All these hormonal and metabolic effects were similar to, but of greater magnitude than those we observed with a lower infusion rate of beta endorphin $\left(0.06 \mu \mathrm{g} \cdot \mathrm{kg}^{-1} \cdot \mathrm{min}^{-1}\right)$ [4]. As the plasma beta endorphin levels attained were approximately twice as high with the higher infusion rate this confirmed a dose-response effect of beta endorphin on carbohydrate metabolism [11-13]. Although circulating beta endorphin levels were higher than usually seen under conditions of stress such as endotoxaemia [24], they were of the same order of magnitude as seen in the hypothalamic venous effluent in monkeys [25] when peripheral levels were only $0.013 \mathrm{nmol} / 1$ suggesting that very high beta endorphin levels may be necessary at the site of action for optimal effectiveness.

The high infusion rate of beta endorphin interfered with the stimulatory effect of epinephrine on hepatic glucose production, despite lower insulin levels. This may have been related to the diminished glucagon response, particularly during the recovery period. The attenuation of epinephrine-stimulated hepatic glucose production by beta endorphin offset the exaggerated suppression of glucose metabolic clearance, thus resulting in equivalent glycaemia to that observed with epinephrine alone. In contrast, the lower infusion rate of beta endorphin did not suppress the stimulatory effect of the first epinephrine infusion on the liver, but did potentiate epinephrine's suppressive effect on metabolic clearance rate (MCR) [4]. Thus the higher rate of infusion resulted in qualitatively different as well as quantitively greater metabolic effects.

With the infusion of beta endorphin alone at $0.06 \mu \mathrm{g} \cdot \mathrm{kg}^{-1} \cdot \mathrm{min}^{-1}$ [26] plasma glucagon rose significantly and stayed elevated throughout the infusion period. Despite this rise in plasma glucagon, there were transient decreases in hepatic glucose production and plasma glucose levels. It has been shown that both beta endorphin and morphine can suppress hepatic glucose production, even when insulin and glucagon are clamped at basal levels [13, 27], suggesting that beta endorphin can act to decrease $R_{a}$ independent of changes in pancreatic hormone secretion. This is consistent with our observations that a high rate of infusion of naloxone can ameliorate insulin-induced hypoglycaemia via potentiation of hepatic glucose production [7]. However, in isolated rat hepatocytes, beta endorphin has been shown to have no effect on basal or glucagon-stimulated glucose production [28]. The underlying mechanism by which the endogenous opiates may modulate glucose production by the liver has not been characterised. Epinephrine's effects on hepatic glucose production have been shown to involve stimulation of both glycogenolysis and gluconeogenesis $[29,30]$ and beta endorphin could decrease either or both. Also, the site at which beta endorphin acts to decrease $R_{a}$, in the 
present study, is not clear, as both the liver and the central nervous system are potential targets for the actions of beta endorphin [13, 23, 31-33]. Receptors for beta endorphin have been detected in the liver, but these receptors appear to be non-opiate in nature [31].

The increase in beta endorphin in alloxan-diabetic dogs was, somewhat surprisingly, 5-fold greater than that seen in normal dogs suggesting impaired clearance in diabetes. This could have clinical relevance with respect to mentation during developing metabolic deterioration in some diabetic patients. Even with the markedly elevated beta endorphin levels in the diabetic animals, beta endorphin $\left(0.3 \mu \mathrm{g} \cdot \mathrm{kg}^{-1} \cdot \mathrm{min}^{-1}\right)$ did not significantly alter the effects of epinephrine on glucose concentration or kinetics. Also, beta endorphin failed to suppress plasma glucagon levels with either epinephrine infusion, and in fact there was an unexplained augmentation of glucagon release in response to the first epinephrine infusion. This could relate to a relative lack of paracrine inhibition of glucagon secretion because of chronic hypoinsulinaemia in the alloxan-diabetic dogs. However, it is true that beta endorphin did suppress the insulin response to the second epinephrine infusion in normal dogs, and this was not accompanied by exaggerated hyperglucagonaemia. The lack of glucagon suppression by beta endorphin could have contributed to the lack of suppression of hepatic glucose production whereas in normal animals with a similar infusion rate of beta endorphin both the glucagon responses and $\mathrm{Ra}$ were diminished. It is possible that, in diabetic dogs, beta endorphin has a direct inhibitory effect on $R_{a}$, for the augmented glucagon response did not give rise to an augmentation in $R_{a}$ during the first epinephrine infusion period. This might have been expected in view of the fact that glucagon and epinephrine have been shown to have a synergistic hyperglycaemic effect in the dog [34], and diabetes is associated with increased sensitivity to epinephrine [35]. However, beta endorphin did not give rise to an augmented glucagon response to the second epinephrine infusion or when given with epinephrine to normal dogs. Also, beta endorphin failed to stimulate glucagon release in vitro [28]. With hypoinsulinaemia, both glucagon release and glucose production in response to epinephrine are augmented [5] and it is possible that under such conditions, the inhibitory effects of beta endorphin are not expressed. Similarly in severe diabetes, glucagon suppression does not attenuate hepatic glucose production or ameliorate hyperglycaemia [36]. Thus with severe insulin deficiency, the effectiveness of some modulatory hormones may be diminished.

The failure of beta endorphin to modulate epinephrine's effect on glucose clearance in the diabetic animal could relate to a lack of suppression of the residual insulin secretion preventing a further decrease in glucose clearance. This is in contrast to normal ani- mals in which beta endorphin suppressed epinephrineinduced insulin secretion and glucose clearance. Epinephrine infusion during prevailing hypoinsulinaemia resulted in decreased glucose clearance and it is possible that clearance could not decrease further with the addition of beta endorphin. In addition, a considerable portion of measured glucose clearance may be accounted for by glycosuria in the diabetic animals. The suppressive effects of beta endorphin on metabolic glucose clearance may therefore be greatly underestimated in the present study, particularly as there is no evidence to suggest that beta endorphin can alter renal clearance of glucose. Thus a small percentage change in total glucose clearance could be associated with a substantial change in metabolic glucose clearance.

The possibility that some of the effects of beta endorphin on glucose kinetics are mediated through growth hormone release must be considered. In rats, systemic administration of opioid peptides has been reported to stimulate growth hormone release [37]. This appears to occur through a centrally-mediated mechanism, and can be blocked by naloxone. Hyperglycaemic effects of growth hormone can be detected within $4 \mathrm{~h}$ of administration, particularly in insulin-deficient states [38]. Thus, in our studies, which were conducted over a 270-min time period, modulation of glucose kinetics by beta endorphin-stimulated growth hormone release cannot be excluded.

In conclusion repeated epinephrine infusions induce exaggerated hyperglycaemia due to exaggerated and sustained increases in glucagon and hepatic glucose production in alloxan-diabetic dogs. In normal dogs, beta endorphin $\left(0.3 \mu \mathrm{g} \cdot \mathrm{kg}^{-1} \cdot \mathrm{min}^{-1}\right)$ suppressed epinephrine-induced insulin and glucagon release and potentiated the inhibitory action of epinephrine on the metabolic clearance of glucose. However epinephrineinduced hyperglycaemia was not appreciably altered by beta endorphin because of concomitant suppression of hepatic glucose production. In contrast, beta endorphin did not modulate the effects of epinephrine on glucose kinetics and failed to inhibit glucagon and insulin secretion in response to epinephrine in the alloxan-diabetic dogs. We feel that the failure of beta endorphin to modulate the glucoregulatory responses to epinephrine in the diabetic animals is related to the markedly reduced residual insulin secretion.

Acknowledgements. We are grateful to N.Kovacevic, D. Bilinski, and E. Cook for their excellent assistance and L. Payne and S. Dow for their help in the preparation of the manuscript. The work in this paper was supported by the Medical Research Council of Canada, the Canadian Diabetes Association, Juvenile Diabetes Foundation International, the Women's College Hospital Research Fund and the Banting and Best Diabetes Centre. Dr. K.M.A. El-Tayeb was a doctoral student sponsored by the University of Gezira, Sudan and the University of Toronto Life Sciences Fellowship. Dr. P.L. Brubaker was a Juvenile Diabetes Foundation International Post-doctoral Fellow. 


\section{References}

1. Wilmore DW (1976) Carbohydrate metabolism in trauma. Clin Endocrinol Metab 5: 731-745

2. Halter JB, Beard JC, Porte D Jr (1984) Islet function and stress hyperglycemia: plasma glucose and epinephrine interaction. Am J Physiol 247: E47-E 52

3. Bondy PK, Felig P (1974) Disorders of carbohydrate metabolism. Bondy PK, Rosenberg LE (eds) Duncan's diseases of metabolism, 7th edn. Saunders, Philadelphia, pp 221-340

4. El-Tayeb KMA, Brubaker PL, Vranic M, Lickley HLA (1985) Beta endorphin modulation of the glucoregulatory effects of repeated epinephrine infusion in normal dogs. Diabetes 34: 1293-1300

5. Perez G, Kemmer FW, Lickley HLA, Vranic M (1981) Importance of glucagon in mediating epinephrine-induced hyperglycemia in alloxan-diabetic dogs. Am J Physiol 241: E328-E 335

6. Awoke S, Voyles NR, Bhathena SJ, Tanenberg RJ, Recant L (1984) Alterations of plasma opioid activity in human diabetics. Life Sci 34: 1999-2006

7. El-Tayeb KMA, Brubaker PL, Lickley HLA, Vranic M (1986) Effects of opiate receptor blockade on normoglycemia and hypoglycemic glucoregulation. Am J Physiol 250: E236-E242

8. Viveros OH, Diliberto EJ, Hazum E, Chang K-J (1979) Opiatelike materials in the adrenal medulla: evidence for storage and secretion with catecholamines. Mol Pharmacol 16: 1101-1108

9. Lord JAH, Waterfield AA, Hughes J, Kosterlitz HW (1979) Endogenous opioid peptides: multiple agonists and receptors. Nature 267: 495-499

10. Zukin RS, Zukin SR (1981) Multiple opiate receptors: emerging concepts. Life Sci 29: 2681-2690

11. Giugliano D (1984) Morphine, opioid peptides, and pancreatic islet function. Diabetes Care 7: 92-98

12. Ipp E, Dhuorajiwala J, Pugh W, Moosa AR, Rubenstein AH (1982) Effects of an enkephalin analog on pancreatic endocrine function and glucose homeostasis in normal and diabetic dogs. Endocrinology 111: 2110-2116

13. Radosevich PM, Williams PE, Lacy DB, McRae JR, Steiner KE, Cherrington AD, Lacy WW, Abumrad NN (1984) Effects of morphine on glucose homeostasis in the conscious dog. $J$ Clin Invest 74: $1473-1480$

14. Vranic M, Kawamori R, Pek S, Kovacevic N, Wrenshall G (1976) The essentiality of insulin and the role of glucagon in regulating glucose utilization and production in exercising dogs. J Clin Invest $57: 245-255$

15. Christensen NJ, Christensen SE, Hansen AP, Lunder R (1975) The effect of somatostatin on plasma nor adrenaline and plasma adrenaline concentrations during exercise and hypoglycemia. Metabolism 24: 1267-1272

16. Kemmer FW, Lickley HLA, Gray DE, Perez G, Vranic M (1982) State of metabolic control determines role of epinephrine-glucagon interaction in glucoregulation in diabetes. Am J Physiol 242: E428-E 436

17. Gauthier C, El-Tayeb K, Vranic H, Lickley HLA (1986) Glucoregulatory role cortisol and epinephrine interactions studied in adrenalectomized dogs. Am J Physiol 250: E393-E401

18. Steele R (1959) Influence of glucose loading and of injected insulin on hepatic glucose output. Ann NY Acad Sci 82: 420-430

19. Radziuk J, Norwich KH, Vranic M (1978) Experimental validating of measurements of glucose turnover in nonsteady state. Am J Physiol 234: E84-E93

20. Radziuk J, Lickley HLA (1985) The metabolic clearance of glucose: measurement and meaning. Diabetologia $28: 315-322$

21. Winer BJ (1971) Statistical principles in experimental design. McGraw-Hill, New York
22. Reid RL, Yen SSC (1981) B-endorphin stimulates the secretion of insulin and glucagon in humans. J Clin Endocrinol Metab 52: 592-594

23. Ipp E, Dobbs RH (1978) Morphine and B-endorphin influence the secretion of the endocrine pancrease. Nature (London) 276: 190-191

24. Bone RC, Jacobs ER, Potter DM, Hiller FC, Wilson FJ Jr (1981) Endorphins in endotoxin shock. Microcirculation 1: 285-295

25. Wardlaw SL, Wehrenberg WB, Ferin M, Carmel PW, Frantz AG (1980) High levels of B-endorphin in hypophyseal portal blood. Endocrinology 106: 1323-1326

26. El-Tayeb KMA, Gauthier CJT, Brubaker PL, Lickley HLA, Vranic M (1986) Hormonal and metabolic responses to intracarotid and intrajugular infusion of B-endorphin in normal dogs. Can J Physiol Pharmacol 64: 306-310

27. Radosevich PM, Williams PE, McRae JR, Lacy WW, Orth DN, Abumrad NN (1984) B-endorphin inhibits glucose production in the conscious dog. J Clin Invest 73: 1237-1241

28. Brubaker PL, Sun A, Vranic M (1987) Lack of effect of B-endorphin on basal or glucagon-stimulated hepatic glucose production in vitro metabolism. Metabolism 36:432-437

29. Sacca L, Vigorito C, Cicala M, Corso G, Sherwin RS (1983) Role of gluconeogenesis in epinephrine-stimulated hepatic glucose production in humans. Am J Physiol 245: E294-E302

30. Cherrington AD, Fuchs H, Stevenson RW, Williams PE, Alberti KGMM, Steiner KE (1984) Effect of epinephrine on glycogenolysis and gluconeogenesis in conscious overnight-fasted dogs. Am J Physiol 247: E137-E144

31. Dave JR, Rubinstein N, Eskay RL (1985) Evidence that B-endorphin binds to specific receptors in rat peripheral tissues and stimulates the adenylate cyclose-adenosine 3,5-menophosphate system. Endocrinology 117: 1389-1396

32. Shimazu T (1981) Central nervous system regulation of liver and adipose tissue metabolism. Diabetologia 20:343-356

33. Pardridge WM (1984) Transport of nutrients and hormones through the blood-brain barrier. Fed Proc 43: 201-204

34. Eigler N, Sacca L, Sherwin RS (1979) Synergistic interactions of physiologic increments of glucagon, epinephrine and cortisol in the dog. J Clin Invest 63: 114-123

35. Shamoon H, Hendler R, Sherwin RS (1980) Altered responsiveness to cortisol, epinephrine and glucagon in insulin-infused juvenile-onset diabetes. Diabetes 29: 284-291

36. Lickley HLA, Kemmer FW, Doi K, Vranic M (1983) Glucagon suppression improves glucoregulation in moderate but not severe diabetes. Am J Physiol 245: E424-E 429

37. Shaar CJ, Frederickson RCA, Dininger NB, Jackson L (1977) Enkephalin analogues and naloxone modulate the release of growth hormone and prolactin - evidence for regulation by an endogenous opioid peptide in brain. Life Sci 21: 853-860

38. Metcalfe P, Johnston DG, Nosadini R, Orksov H, Alberti KGMM (1981) Metabolic effects of acute and prolonged growth hormone excess in normal and insulin-deficient man. Diabetologia 20: $123-128$

Received: 12 February 1987

and in revised form: 29 July 1987

Dr. L. Lickley

c/o Department of Physiology

Room 3358, Medical Sciences Building

University of Toronto

Toronto, Ontario, M5S 1 A8

Canada 